\title{
LKMA Evaluation Formed from PUAP Program in Overcoming Farming Financing in Rural Areas (Case study: Magelang Regency)
}

\author{
Valeriana Darwis ${ }^{1, *}$, Ashari $^{1}$, and Chairul Muslim ${ }^{1}$ \\ ${ }^{1}$ Indonesia Center for Agricultural Socio Economic and Policy Studies, Jl. Tentara Pelajar No. 3B \\ Cimanggu Bogor West Java, Indonesia 16161
}

\begin{abstract}
Rural Agribusiness Development (PUAP) is a program to provide capital for smallholder in the agricultural sector. The final goal of this program is to format Agribusiness Micro Credit Institutions (LKMA) in rural. In the implementation 6,887 LKMAs have been formed, including in Magelang Regency. The purpose of this paper is to evaluate the LKMA and its benefit for farmers' capital fulfillment. The survey was conducted in July 2019 using the FGD method with administrators and interviews with the farmer using a questionnaire. The evaluation focused on the institutional, business, and capital development aspects. The data analyzed through the ranking method to determine the LKMA rank. Of the 9 LKMA, the best LKMA is Ngudi Luhur LKMA, with criteria (i) the institutional aspect is already incorporated, has an office, employees with a fixed monthly salary; (ii) business aspects: saving and loan business carried out based on SOP of financial institutions and (iii) of capital development have reached 3.3 billion. However, loans only cover less than $30 \%$ of farmers' needs due to the limited availability of LKMA capital. Therefore, it is recommended to assist capital loan assistance to LKMA, which will then be transmitted to farmmers.
\end{abstract}

\section{Introduction}

The concept of financial inclusion emerged in the 2000s as a more comprehensive way to justify the need to establish financial services [1]. It indicates that everyone should have access to financial services at reasonable prices (interest) in a suitable manner with respect and dignity. In the agricultural context [2] proposed that Microfinance has been considered as a pathway for smallholder farming. [3] believed that extension of credit services will have great impacts on agriculture production of society farmers and rural incomes. However, the effectiveness of microfinance in supporting the agricultural industry still debatable. For instance, [4] reported that microfinance is regarded as a powerful instrument in Vietnam's economy. Nevertheless, the study of [5] found no significant impact of microfinance on agriculture industry performance in Pakistan. The condition of social, economic, and natural resources contributes to the level of microfinance.

\footnotetext{
* Corresponding author: valicfurca@gmail.com
} 
Microfinance institutions provide essential financial services (such as loans, savings, and insurance) to low-income individuals, for whom it is not feasible (possible) to access financial services [6]. For the agricultural sector, financial support is urgent because many farmers tend to a shortage of funds. Agricultural microfinance is supposed to play a significant role in facilitating the improvement of the agricultural sector. The study [7] found that microfinance is positively related to agricultural production and significantly impacts yield levels. Especially for Indonesia, the findings study of [8] stated that microfinance has the opportunity to contribute to the existing schemes of climate change adaptation for agriculture.

However, banking prudence in channeling credit to the agricultural sector, causing farmers to have difficulty in borrowing venture capital. This caution is because farmers do not have enough collateral and the production of farming almost all is not durable [9]. Therefore farmers are more likely to borrow capital from informal financing institutions that are burdensome and ultimately do not provide benefits [10]. As a matter of fact, the capital factor is one of the problems in increasing productivity [11].

In overcoming the problem of farming financing, the government has issued several programs, and one of them is the Rural Agribusiness Development which is called PUAP Program. This program is in the form of venture capital assistance for farmers, landowners, tenants, and farm laborers [12]. The support provided does not involve formal financial institutions, but it directly gives to the Farmers Group Association (FGA) with value of 100 million IDR/FGA. Every FGA is expected to create an Agribusiness Microfinance Institution which is called LKMA whose task is to manage aid funds independently.

PUAP program aims to: (i) reduce poverty and unemployment by growing and developing agribusiness business activities in rural areas according to regional potential; (ii) increasing the ability and knowledge of agribusiness entrepreneurs, FGA management, Extension and Supervision of Farmer Partners; (iii) empowering farmer institutions and the rural economy for the development of agribusiness business activities and (iv) enhancing the functioning of farmer economic institutions into networks or partners of financial institutions in the context of access to capital [13]

The PUAP program was implemented from 2008 to 2015 . The number of villages in Indonesia receiving the program is 52,186 villages. Each village is represented by a FGA and it is expected that each FGA will later form LKMA. But in its implementation LKMA formed only 6,887 units. The low formation of $L K M A$ is due to: (i) it was established at the initiative of the government, the membership and ownership status of LKMA is unclear, (ii) uncertainty also in the distribution of rights and obligations for each member and management, (iii) it is difficult to achieve economic and difficult business scale maintain its sustainability, (iv) expect the savings of members and non-members are also difficult because saving funds in LKMA have a great risk [14].

All matters above could have happened because establishing an institution is quite sophisticated. It takes time to strengthen the existence of poor farmers groups and other related institutions [15]. Gapoktan failed to develop PUAP funds because: (i) Human resources capacity was not able to manage the revolving fund, (ii) there were still farmers who were late even did not return loan funds, and (iii) use of funds for non-productive activities [16-18]. On the other hand, the positive impacts of the PUAP program at the farmer level are: (i) increased insights about savings and loans, (ii) increased interaction between farmers, (iii) obtaining loans with security procedures and conditions, (iv) not being tied to intermediaries and (v) farmers' income and employment opportunities will increase[19-21].

Regarding the benefits and problems in implementing the PUAP program, this paper aims to evaluate how the implementation of running the LKMA, especially in institutional, 
business implementation, business development aspects, and how much the benefits for farmers in fulfillment of capital needs effort.

\section{Methodology}

The survey was conducted in July 2019 in Magelang District. The research location was defined purposively based on the criteria of the districts that previously received PUAP program assistance. As the unit analysis in this survey is GFA that has formed LKMA. The respondent is the administrator of LKMA that has obtained a business license from the Financial Services Authority (FSA/OJK). From these criteria, 9 AMFI finally was chosen as shown in table 1 below.

Table 1. LKMA in Magelang District Has Already Got a Business License from OJK

\begin{tabular}{|l|l|r|r|}
\hline \multirow{2}{*}{ No } & \multicolumn{1}{|c|}{ LKMA } & \multicolumn{2}{|c|}{ Address } \\
\cline { 3 - 4 } & & Village & \multicolumn{1}{c|}{ Subdistrict } \\
\hline 1 & LKMA Maju Makmur & Borobudur & Borobudur \\
\hline 2 & LKMA Tani Makmur & Kalibening & Dukun \\
\hline 3 & LKMA Sukses Makmur & Sumber & Dukun \\
\hline 4 & LKMA Tani Sukses Mandiri & Krinjing & Dukun \\
\hline 5 & LKMA Randu Makmur & Seloboro & Suntilan \\
\hline 6 & LKMA Ngudi Luhur & Krasak & Salaman \\
\hline 7 & LKMA Merapi Sejahtera & Kaliurang & Srumbung \\
\hline 8 & LKMA Tani Makmur Merapi & Tegal Randu & Srumbung \\
\hline 9 & LKMA Arta Makmur & & \\
\hline
\end{tabular}

Source: Directorate of Agricultural Financing. 2018 [22]

The data in this study consisted of primary data and secondary data. Primary data was collected through (i) direct interviews with 27 borrower (farmers) using a questionnaire focusing on farming; each LKMA was represented by three farmers representing the most borrowed subsectors and (ii) FGD with LKMA management in terms of the experience of running a business. Meanwhile, secondary data was obtained from LKMA relating to institutional, business, and loan requirements as well as financial statements.

The collected data then was analyzed using: (i) descriptive analysis to look at the performance of LKMA implementation; (ii) LKMA evaluation using ranking methods; and (iii) the magnitude of the benefits of venture capital loans for farmers is obtained by comparing the number of loans with the number of business costs. The data collected is then analyzed using: (i) descriptive analysis to look at the performance of LKMA implementation; (ii) LKMA evaluation using ranking methods; and (iii) the magnitude of the benefits of venture capital loans for farmers is obtained by comparing the number of loans with the number of business costs.

\section{Results and Discussion}

\subsection{The Role of Local Government}

Although the national PUAP program activities have ended, but in its development is still a concern of local governments. This was represented by the issuance of Magelang District Decree No. 180,182/62/KEP/01.03/2019 concerning the Team Advisor, Monitoring and Evaluation of Microfinance Financial Institutions of Magelang District, 2019. This Regent's Decree is a spirit to encourage the Micro Finance Institution in the economic and industrial 
development, especially micro industries and home industries so as to create a good business climate and expand employment. The tasks of the team formed include:

1. Conduct an inventory of microfinance institutions in Magelang District

2. Coordinating and implementing guidance, guidance and assistance for microfinance institutions in the context of preparation to become a legal microfinance institution

3. Make efforts towards strengthening institutions and developing human resources management

4. Carry out monitoring and evaluation activities on the development of microfinance institutions.

One of the tasks of the district development and monitoring team is to assist LKMA management in legality management. This team in 2019 succeeded in helping the legal status of 9 LKMA who had obtained FSA/OJK licenses to become cooperatives. This status change causes name changes and different name changes, some use the name: LKMA Cooperative, Gapoktan LKMA Cooperative and others use Farmer Cooperatives (Table 2).

Table 2. Changes in LKMA Names

\begin{tabular}{|c|l|l|}
\hline No & \multicolumn{1}{|c|}{$\mathbf{2 0 1 8}$} & \multicolumn{1}{c|}{$\mathbf{2 0 1 9}$} \\
\hline 1 & LKMA Maju Makmur & Koperasi LKMA Maju Makmur Kalipucang \\
\hline 2 & LKMA Tani Makmur & Koperasi Tani Makmur \\
\hline 3 & LKMA Sukses Makmur & Koperasi LKMA Gapoktan Sukses Makmur \\
\hline 4 & LKMA Tani Sukses Mandiri & Koperasi LKMA Tani Sukses Mandiri \\
\hline 5 & LKMA Randu Makmur & Koperasi LKMA Randu Makmur \\
\hline 6 & LKMA Ngudi Luhur & Koperasi LKMA Ngudi Luhur \\
\hline 7 & LKMA Merapi Sejahtera & Koperasi LKMA Tani Merapi Sejahtera \\
\hline 8 & LKMA Tani Makmur Merapi & Koperasi Tani Makmur Merapi Kerinjing \\
\hline 9 & LKMA Arta Makmur & Koperasi LKMA Arta Makmur Sejahtera \\
\hline
\end{tabular}

\subsection{Evaluation of LKMA Activities}

\subsubsection{Institutional Aspects}

In this study, as the object of research is $L K M A$, which in 2018 had obtained a business license from OJK. When the survey conducted in 2019, the LKMA had become a cooperative. Therefore, LKMA has been authorized by two agencies, i.e., the Ministry of Cooperatives and the Ministry of Finance. One example of such legality is the LKMA Ngudi Luhur Cooperative, which was inaugurated by the OJK based on Kep-05 / NB.123 / 2015 and Magelang District Decree No. 180,182 / 501 / KEP / 26/2015. The cooperative has a vision: "the realization of an independent and prosperous Kaliurang Village community." The mission was realized by "providing savings and loan services based on a sincere spirit to work together to help each other in overcoming the problem of limited capital for the farming community to improve the family economy".

From LKMA surveyed, only LKMA Ngudi Luhur runs activities in offices or special rooms. Many other LKMA work in one room of the house owned by the management or members with hitchhiking status. Such status is not high costs and not fixed payment every year, because it is adjusted to the Cooperative income. But, it does not occur in the LKMA Ngudi Luhur Cooperative, which allocates a budget for office rent IDR 3,000,000/ year. In conducting its activities, all LKMA' officer have used computers. This is reasonable, because previously the OJK have obliged each LKMA to make financial reports with computers and reported periodically (every year) by online. Office equipment other than computers and printers is only owned by LKMA Ngudi Luhur. The equipment such as 
filing cabinets, desks and chairs are available in every room. At LKMA Ngudi Luhur, there is a special room for customers to do transactions.

All LKMA already have an organizational structure and management. Recruitment of management can initiate from several alternatives, namely (i) all from outside FGA, (ii) all management from FGA, or (iii) a combination of FGA and outside FGA. Administrators will get incentives based on LKMA income. The stimuli were obtained in two ways, namely: (i) at the time of the equity (SHU) distribution at the end of each year, and all LKMA implemented it; (ii) incentives given every month applied at 8 LKMA. Only LKMA Tani Makmur does not provide monthly incentives to the management. LKMA Ngudi Luhur provides the highest incentive as much as IDR. 1,000,000 for managers and IDR. 900,000 for staff. To see the institutional aspects and the process of calculating the ranking, see Table 3.

Table 3. Institutional Aspects and Ranking Calculation

\begin{tabular}{|c|c|c|c|c|c|c|c|c|c|c|c|c|c|}
\hline \multirow[t]{2}{*}{$\begin{array}{c}\mathbf{N} \\
\mathbf{0}\end{array}$} & \multirow[t]{2}{*}{ LKMA } & \multicolumn{2}{|c|}{ Legal entity } & \multicolumn{3}{|c|}{ Office } & \multicolumn{2}{|c|}{$\begin{array}{c}\begin{array}{c}\text { Office } \\
\text { equipment }\end{array} \\
\end{array}$} & \multicolumn{2}{|c|}{ Caretaker } & \multicolumn{2}{|c|}{ Incentive } & \multirow{2}{*}{$\begin{array}{c}\text { Sc } \\
\text { or } \\
\text { e }\end{array}$} \\
\hline & & $\begin{array}{c}\text { Coo } \\
\text { pera } \\
\text { tive }\end{array}$ & OJK & $\begin{array}{c}\mathrm{Re} \\
\mathrm{nt}\end{array}$ & $\begin{array}{c}\text { Belo } \\
\text { ngs } \\
\text { to }\end{array}$ & $\begin{array}{c}\text { Hitc } \\
\text { hhik } \\
\text { e }\end{array}$ & $\begin{array}{c}\text { Com } \\
\text { pute } \\
\mathbf{r}\end{array}$ & $\begin{array}{l}\text { Furn } \\
\text { iture }\end{array}$ & FGA & $\begin{array}{l}\text { Non- } \\
\text { FGA }\end{array}$ & $\begin{array}{l}\text { de } \\
\text { vi } \\
\text { de } \\
\text { nt }\end{array}$ & $\begin{array}{c}\text { Salary } \\
\text { (mont } \\
\text { h) }\end{array}$ & \\
\hline 1 & $\begin{array}{l}\text { Maju } \\
\text { Makmur } \\
\text { Kalipucang }\end{array}$ & 1 & 1 & 0 & 0 & 1 & 1 & 0 & 0 & 1 & 1 & 1 & 7 \\
\hline 2 & $\begin{array}{l}\text { Tani } \\
\text { Makmur }\end{array}$ & 1 & 1 & 0 & 0 & 1 & 1 & 0 & 0 & 1 & 1 & 0 & 6 \\
\hline 3 & $\begin{array}{l}\text { Sukses } \\
\text { Makmur }\end{array}$ & 1 & 1 & 0 & 0 & 1 & 1 & 0 & 0 & 1 & 1 & 1 & 7 \\
\hline 4 & $\begin{array}{l}\text { Tani } \\
\text { Sukses } \\
\text { Mandiri }\end{array}$ & 1 & 1 & 0 & 0 & 1 & 1 & 0 & 0 & 1 & 1 & 1 & 7 \\
\hline 5 & $\begin{array}{l}\text { Randu } \\
\text { Makmur }\end{array}$ & 1 & 1 & 0 & 0 & 1 & 1 & 0 & 1 & 1 & 1 & 1 & 8 \\
\hline 6 & $\begin{array}{l}\text { Ngudi } \\
\text { Luhur }\end{array}$ & 1 & 1 & 1 & 0 & 0 & 1 & 1 & 1 & 1 & 1 & 1 & 9 \\
\hline 7 & $\begin{array}{l}\text { Tani } \\
\text { Merapi } \\
\text { Sejahtera }\end{array}$ & 1 & 1 & 0 & 0 & 1 & 1 & 0 & 1 & 1 & 1 & 1 & 8 \\
\hline 8 & $\begin{array}{l}\text { Tani } \\
\text { Makmur } \\
\text { Merapi } \\
\text { Kerinjing }\end{array}$ & 1 & 1 & 0 & 0 & 1 & 1 & 1 & 1 & 0 & 1 & 1 & 8 \\
\hline 9 & $\begin{array}{l}\text { Arta } \\
\text { Makmur } \\
\text { Sejahtera }\end{array}$ & 1 & 1 & 0 & 0 & 1 & 1 & 0 & 0 & 1 & 1 & 1 & 7 \\
\hline
\end{tabular}

Note: $0=$ no $1=$ yes

\subsubsection{Business Implementation Aspects}

After becoming a cooperative, each LKMA or cooperative member is obliged to pay the principal savings that apply once and the mandatory savings paid every month. The highest savings is IDR 50,000 and the lowest is IDR 20,000. Whereas the highest monthly compulsory contributions are IDR 10,000 and the lowest is IDR 2,000.

All LKMA have savings and loan activity. Members who save will get $0.01 \%$ interest annually. LKMA which does not require members to save money is only LKMA Tani Makmur. Borrowing members will be charged interest by determining the amount as follows: (i) a fixed interest of 1 to $1.6 \%$ per month without differentiating the type of 
business and (ii) interest between 1 to $3 \%$ per month based on a predetermined loan scheme. LKMA which uses a loan scheme is only LKMA Ngudi Luhur.

Besides interest, LKMA requires borrowers to pay administrative costs when borrowing. Administrative costs differ between LKMA; for example, LKMA Sukses Makmur applies administrative costs each time it borrows IDR 15,000. While LKMA Maju Makmur collected an administration fee of IDR 10,000. Another LKMA applies administration fees as a percentage, which is $1 \%$ of the total loan. Additional fees will be charged for borrowers who are late in paying monthly installments. All LKMA applies late fees for paying monthly bills. Late fees for paying monthly bills are set in nominal terms and based on a percentage. At LKMA Arta Makmur Sejahtera for those who are late paying a penalty of IDR 1,000 per day. While in LKMA Ngudi Luhur, the cost of late paying bills is $1.5 \%$ of monthly payment obligations.

Members who borrow business capital from LKMA Tani Makmur do not need to submit a loan letter because the borrower's data and information already exist in LKMA. Collateral is also not required for members who borrow at LKMA Maju Makmur, LKMA Tani Makmur, LKMA Sukses Makmur, and LKMA Makmur Merapi Kerinjing. Collateral is not required for borrowers because: (i) the amount of the loan is not large, (ii) is stayed in the same village, and (iii) there is no special place for storing collateral. To see aspects of business implementation and the process of calculating its ranking, see Table 4.

Table 4. Aspects of Business Implementation and Ranking Calculation

\begin{tabular}{|c|c|c|c|c|c|c|c|c|c|c|c|c|}
\hline \multirow[t]{3}{*}{ No } & \multirow{3}{*}{$\begin{array}{c}\text { LKMA } \\
\text { Name }\end{array}$} & \multicolumn{2}{|c|}{ Business } & \multirow{3}{*}{$\begin{array}{c}\text { Rate } \\
\text { Loan } \\
\text { per } \\
\text { mont } \\
\text { h } \\
(\%)\end{array}$} & \multicolumn{3}{|c|}{ Other Costs (\%) } & \multicolumn{4}{|c|}{ Borrowing Requirements } & \multirow[t]{3}{*}{ Amount } \\
\hline & & \multirow[t]{2}{*}{$\begin{array}{l}\text { Savin } \\
\text { gs }\end{array}$} & \multirow[t]{2}{*}{$\begin{array}{l}\text { Loa } \\
\text { ns }\end{array}$} & & \multirow{2}{*}{$\begin{array}{c}\text { Prov } \\
\text { i } \\
\text { sion }\end{array}$} & \multirow[t]{2}{*}{$\overline{\text { ADM }}$} & \multirow[t]{2}{*}{ Fine } & \multicolumn{2}{|c|}{$\begin{array}{c}\text { Letter of } \\
\text { Submission }\end{array}$} & \multicolumn{2}{|c|}{ Collateral } & \\
\hline & & & & & & & & Yes & No & Yes & No & \\
\hline 1 & $\begin{array}{l}\text { Maju } \\
\text { Makmur } \\
\text { Kalipucang }\end{array}$ & 1 & 1 & 1,5 & 0 & 1 & 1 & 1 & 0 & 0 & 0 & 5 \\
\hline 2 & $\begin{array}{l}\text { Tani } \\
\text { Makmur }\end{array}$ & 0 & 1 & 1 & 0 & 1 & 0 & 0 & 0 & 0 & 0 & 3 \\
\hline 3 & $\begin{array}{l}\text { Sukses } \\
\text { Makmur }\end{array}$ & 1 & 1 & 1 & 0 & 1 & 0 & 1 & 0 & 0 & 0 & 4 \\
\hline 4 & $\begin{array}{l}\text { Tani } \\
\text { Sukses } \\
\text { Mandiri }\end{array}$ & 1 & 1 & 1 & 0 & 1 & 1 & 1 & 0 & 1 & 0 & 6 \\
\hline 5 & $\begin{array}{l}\text { Randu } \\
\text { Makmur }\end{array}$ & 1 & 1 & 1 & 0 & 1 & 1 & 1 & 0 & 1 & 0 & 6 \\
\hline 6 & $\begin{array}{l}\text { Ngudi } \\
\text { Luhur }\end{array}$ & 1 & 1 & $1-3$ & 0 & 1 & 1 & 1 & 0 & 1 & 0 & 6 \\
\hline 7 & $\begin{array}{l}\text { Tani } \\
\text { Merapi } \\
\text { Sejahtera }\end{array}$ & 1 & 1 & 1 & 0 & 1 & 1 & 1 & 0 & 1 & 0 & 6 \\
\hline 8 & $\begin{array}{l}\text { Tani } \\
\text { Makmur } \\
\text { Merapi } \\
\text { Kerinjing }\end{array}$ & 1 & 1 & 1,5 & 0 & 1 & 0 & 1 & 0 & 0 & 0 & 4 \\
\hline 9 & $\begin{array}{l}\text { Arta } \\
\text { Makmur } \\
\text { Sejahtera }\end{array}$ & 1 & 1 & 1,6 & 0 & 1 & 1 & 1 & 0 & 1 & 0 & 6 \\
\hline
\end{tabular}

\subsubsection{Business Development Aspects}

The timing of capital listing is not the same in every LKMA, some start in 2013, 2014, 2015, 2016 and even some only record venture capital in 2016 alone, as happened in LKMA Sukses Makmur (Table 5). How many people who borrow each year is recorded very well only in LKMA Ngudi Luhur, LKMA Tani Merapi sejahtera, LKMA Maju Makmur Kalipucang and LKMA Tani Makmur. 
The largest development of venture capital and the largest number of borrowers occurred in LKMA Ngudi Luhur. In 2013 the venture capital in LKMA Ngudi Luhur amounted to 967 million and increased in 2018 to 3.4 billion. Over a period of 6 years the average business capital in LKMA Ngudi Luhur increased by 29.86 percent per year. While the number of borrowers in LKMA Ngudi Luhur from 2013 to 2018 increased on average each year by $18.76 \%$. The increase in business capital for the next order is LKMA Randu Makmur and LKMA Tani Merapi Sejahtera. The increase for each LKMA averaged $13.47 \%$ and $8.92 \%$.

Table 5. Aspects of Business Development (IDR 000)

\begin{tabular}{|c|c|c|c|c|c|c|c|c|}
\hline \multirow{2}{*}{$\begin{array}{l}\text { Po } \\
\text { int }\end{array}$} & \multirow[t]{2}{*}{ Description } & \multicolumn{6}{|c|}{ Years } & \multirow{2}{*}{$\begin{array}{l}\text { Average } \\
\text { annual } \\
\text { growth }\end{array}$} \\
\hline & & 2013 & 2014 & 2015 & 2016 & 2017 & 2018 & \\
\hline \multirow[t]{3}{*}{9} & \multicolumn{8}{|c|}{ LKMA Ngudi Luhur } \\
\hline & Capital (000 IDR) & 966,992 & $1,357,472$ & $2,246,023$ & $2,535,739$ & $2,935,479$ & $3,370,466$ & 29.86 \\
\hline & Borrowers (People) & 657 & 885 & 1098 & 1,283 & 1,402 & 1,527 & 18.76 \\
\hline \multirow[t]{3}{*}{8} & \multicolumn{8}{|c|}{ LKMA Randu Mkmur } \\
\hline & Capital (000 IDR) & 391,377 & 451,007 & 487,329 & 543,572 & 710,347 & 723,466 & 13.47 \\
\hline & Borrowers (People & - & - & - & 245 & 222 & 172 & -15.96 \\
\hline \multirow[t]{3}{*}{7} & \multicolumn{8}{|c|}{ LKMA Tani Merapi Sejahtera } \\
\hline & Capital (000 IDR) & 157,461 & 139,342 & 185,583 & 172,550 & 222,012 & 224,856 & 8.92 \\
\hline & Borrowers (People & 176 & 100 & 152 & 105 & 102 & 74 & -10.48 \\
\hline \multirow[t]{3}{*}{6} & \multicolumn{8}{|c|}{ LKMA Tani Makmur } \\
\hline & Capital (000 IDR) & - & - & 123,950 & 170,188 & 171,204 & 146,968 & 7.91 \\
\hline & Borrowers (People & - & - & 70 & 90 & 102 & 109 & 16.26 \\
\hline \multirow[t]{3}{*}{5} & \multicolumn{8}{|c|}{ LKMA Makmur Merapi Kerinjing } \\
\hline & Capital (000 IDR) & - & 118,385 & 139,078 & 154,041 & 144,523 & 153,038 & 6.99 \\
\hline & Borrowers (People & - & - & - & - & - & - & - \\
\hline \multirow[t]{3}{*}{4} & \multicolumn{8}{|c|}{ LKMA Arta Makmur Sejahtera } \\
\hline & Capital (000 IDR) & - & - & 126,423 & 122,856 & 129,137 & 143,208 & 4.39 \\
\hline & Borrowers (People & - & - & - & - & - & - & - \\
\hline 3 & \multicolumn{8}{|c|}{ LKMA Tani Sukses Mandiri } \\
\hline & Capital (000 IDR) & - & - & 145,619 & 154,429 & 154,995 & 161,686 & 3.58 \\
\hline & Borrowers (People & - & - & - & - & - & - & - \\
\hline \multirow[t]{3}{*}{2} & \multicolumn{8}{|c|}{ LKMA Maju Makmur Kalipucang } \\
\hline & Capital (000 IDR) & - & - & 103,621 & 111,979 & 134,013 & 136,859 & 2.69 \\
\hline & Borrowers (People & - & - & 20 & 12 & 67 & 60 & -13.3 \\
\hline \multirow[t]{3}{*}{1} & \multicolumn{8}{|c|}{ LKMA Sukses Makmur } \\
\hline & Capital (000 IDR) & - & - & - & 122,698 & - & - & - \\
\hline & Borrowers (People & - & - & - & - & - & - & - \\
\hline
\end{tabular}

\subsubsection{The Best Rank of LKMA}

By using several assessment criteria, LKMA Ngudi Luhur was selected as the best ranking LKMA in Magelang District (Table 6). Some assessment indicators are as follows:

1. Institutional aspects, LKMA has worked professionally. All managers work in offices that are equipped with adequate office equipment and have permanent employees paid every month

2. Aspects of implementation, already modeled the implementation of loans carried out by formal financial institutions, including the necessity of each borrower to make a loan application letter and have collateral, interest is distinguished based on the time of the loan (tenor), subject to administrative costs and penalties for late monthly installment payments.

3. Business development aspects, with an average increase in the business capital of IDR 40 million per month. 
Table 6. LKMA Best Ranking

\begin{tabular}{|l|c|c|c|c|l|c|}
\hline \multirow{2}{*}{ LKMA Name } & \multicolumn{4}{|c|}{ Aspect } & \multicolumn{2}{c|}{ Business Development } \\
\cline { 2 - 7 } & $\begin{array}{c}\text { Institu } \\
\text { tional }\end{array}$ & $\begin{array}{c}\text { Impleme } \\
\text { ntation }\end{array}$ & Business & Amount & \multicolumn{1}{c|}{ LKMA Name } & Rank \\
\hline Ngudi Luhur & 9 & 6 & 9 & 24 & Ngudi Luhur & 1 \\
\hline Randu Makmur & 8 & 6 & 8 & 22 & Randu Makmur & 2 \\
\hline Tani Merapi Sejahtera & 8 & 6 & 7 & 21 & Tani Merapi Sejahtera & 3 \\
\hline $\begin{array}{l}\text { Arta Makmur } \\
\text { Sejahtera }\end{array}$ & 7 & 6 & 4 & 17 & $\begin{array}{l}\text { Arta Makmur } \\
\text { Sejahtera }\end{array}$ & 4 \\
\hline $\begin{array}{l}\text { Tani Sukses Mandiri } \\
\text { Maju Makmur }\end{array}$ & 7 & 6 & 3 & 16 & $\begin{array}{l}\text { Tani Makmur } \\
\text { Merapi Kerinjing }\end{array}$ & 4 \\
\hline $\begin{array}{l}\text { Tanipucang Makmur Merapi } \\
\text { Kerinjing }\end{array}$ & 8 & 4 & 5 & 17 & Tani Sukses Mandiri & 5 \\
\hline $\begin{array}{l}\text { Sukses Makmur } \\
\text { Tani Makmur }\end{array}$ & 7 & 4 & 1 & 12 & $\begin{array}{l}\text { Maju Makmur } \\
\text { Kalipucang }\end{array}$ & 6 \\
\hline
\end{tabular}

Some excellence of LKMA Ngudi Luhur management compared to other LKMA are as follow:

\section{Savings Products}

LKMA Ngudi Luhur has made several choices in saving, including: (i) Germungtus (Mung Limang Atus Movement), an education savings with competitive services that can only cbe taken at the time of graduation of the child; (ii) Si Mada LKM (Emergency Prepared Deposits), share savings that can only be taken in the event of a disaster / disaster; (iii) Si Hara LKM (Hari Raya) Savings, semi-stock deposits that can only be taken 2 months before Idul Fitri and (iv) Si Bulan LKM (Monthly Savings), deposits that can be taken at any time.

2. Loan Products

LKMA Ngudi Luhur has made several loan schemes, namely:

a. Monthly loans, with conditions:

- Minimum repayment period of 6 months

- Loan interest is $1.5 \%$ flat

- provide collateral loan

- Tolerance of payment of principal and interest installments for 1 month

- Willing to be surveyed and analyzed by loan officers

- Loans can be disbursed after submitting the building and have been verified

- Fill in the SPP (Loan Request Letter) with attached husband and wife FC ID, FC

family maember and collateral guaranteed

b. Weekly loans, terms:

- Minimum repayment period of 6 months

$-2.5 \%$ flat loan interest

- provide collateral loan

- Tolerance of payment of principal and interest installments for 1 week

- Willing to be surveyed and analyzed by loan officers

- Loans can be disbursed after submitting the building and have been verified

- Fill in the SPP (Loan Request Letter) with attached husband and wife FC ID, FC family member and collateral guaranteed

c. Maturity date Loans, terms:

- Minimum repayment period of 6 months

- 3\% flat loan interest

- Collateral loan

- Tolerance of payment of principal and interest installments for 1 month 
- Willing to be surveyed and analyzed by loan officers

- Loans can be disbursed after submitting the building and have been verified

- Fill in the SPP (Loan Request Letter) with attached husband and wife FC ID, FC family member and collateral guaranteed

d. Partnership Loans, terms:

- Minimum repayment period of 6 months

- Loan interest at $0.1 \%$ flat

- Guarantees for guarantees are all deposits, BPKB, Land Certificate, and SK

- Tolerance of payment of principal and interest installments for 1 month

- Willing to be surveyed and analyzed by loan officers

- Loans can be disbursed after submitting the building and have been verified

- Fill in the SPP (Loan Request Letter) with attached husband and wife FC ID, FC KK and collateral guaranteed

3. Already Have Standard Operating Procedure (SOP)

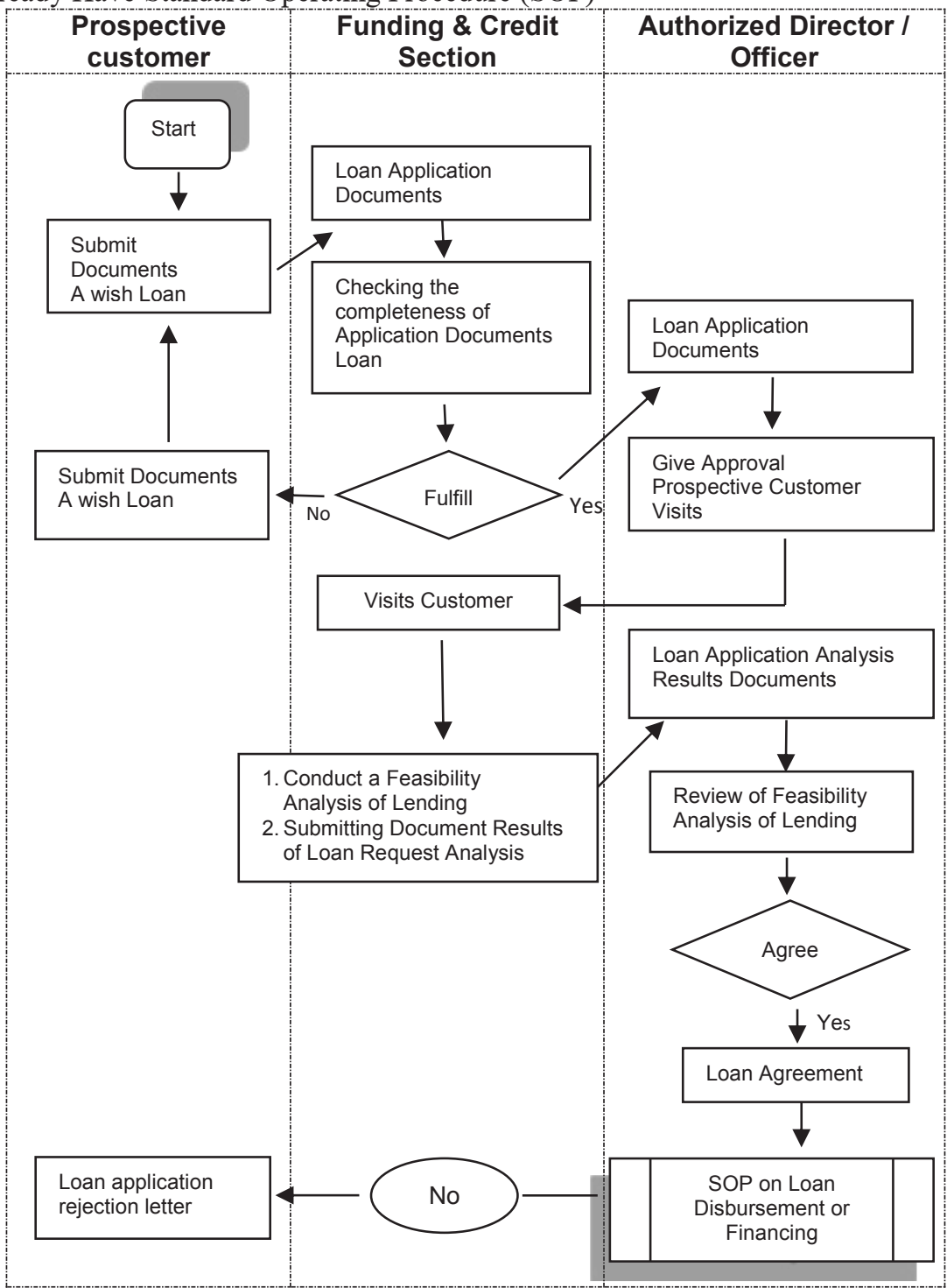

Fig. 1. SOP Loan Application 
These include SOPs for loan applications, loan disbursements, cash payment installments, loan repayments, saving deposits, savings deposits, withdrawals of savings, collection to borrowers and settlement of bad debts. One example is the form of a loan application SOP as shown in figure 1.

4. In carrying out the effort to save $1 \mathrm{kma}$ loan Ngudi Luhur has implemented several SOPs including: (i) SOP for receiving deposits / savings, (ii) SOP of financing (types of products), SOP for member acceptance (principal and mandatory savings), SOP of financing problems and SOP collectability calculation. In addition to having several SOP, LKMA Ngudi Luhur also has several other administrations and can be seen in Table 7.

Table 7. Completeness of Administration Owned by LKMA

\begin{tabular}{|c|c|c|c|c|c|c|c|c|c|}
\hline $\begin{array}{l}\mathbf{N} \\
\mathbf{0}\end{array}$ & $\begin{array}{c}\text { Maju Makmur } \\
\text { Kalipucang }\end{array}$ & $\begin{array}{c}\text { Tani } \\
\text { Makmur }\end{array}$ & $\begin{array}{c}\text { Sukses } \\
\text { Makmur }\end{array}$ & $\begin{array}{c}\text { Tani Sukses } \\
\text { Mandiri }\end{array}$ & $\begin{array}{c}\text { Randu } \\
\text { Makmur }\end{array}$ & $\begin{array}{l}\text { Ngudi } \\
\text { Luhur }\end{array}$ & $\begin{array}{c}\text { Tani } \\
\text { Merapi } \\
\text { Sejahtera } \\
\end{array}$ & $\begin{array}{c}\text { Tani Makmur } \\
\text { Merapi } \\
\text { Kerinjing } \\
\end{array}$ & $\begin{array}{c}\text { Arta } \\
\text { Makmur } \\
\text { Sejahtera }\end{array}$ \\
\hline 1 & $\mathrm{~V}$ & $\mathrm{~V}$ & $\mathrm{~V}$ & $\mathrm{~V}$ & $\mathrm{~V}$ & $\mathrm{~V}$ & $\mathrm{~V}$ & $\mathrm{~V}$ & $\mathrm{~V}$ \\
\hline 2 & $\mathrm{~V}$ & $\mathrm{~V}$ & $\mathrm{~V}$ & $\mathrm{~V}$ & - & $\mathrm{V}$ & $\mathrm{V}$ & $\mathrm{V}$ & $\mathrm{V}$ \\
\hline 3 & - & - & - & - & $\mathrm{V}$ & - & - & - & - \\
\hline 4 & $\mathrm{~V}$ & $\mathrm{~V}$ & $\mathrm{~V}$ & $\mathrm{~V}$ & $\mathrm{~V}$ & $\mathrm{~V}$ & $\mathrm{~V}$ & $\mathrm{~V}$ & $\mathrm{~V}$ \\
\hline 5 & $\mathrm{~V}$ & $\mathrm{~V}$ & $\mathrm{~V}$ & $\mathrm{~V}$ & $\mathrm{~V}$ & $\mathrm{~V}$ & $\mathrm{~V}$ & $\mathrm{~V}$ & $\mathrm{~V}$ \\
\hline 6 & $\mathrm{~V}$ & - & $\mathrm{V}$ & $\mathrm{V}$ & $\mathrm{V}$ & $\mathrm{V}$ & $\mathrm{V}$ & $\mathrm{V}$ & $\mathrm{V}$ \\
\hline 7 & $\mathrm{~V}$ & $\mathrm{~V}$ & $\mathrm{~V}$ & $\mathrm{~V}$ & $\mathrm{~V}$ & $\mathrm{~V}$ & $\mathrm{~V}$ & $\mathrm{~V}$ & $\mathrm{~V}$ \\
\hline 8 & $\mathrm{~V}$ & - & $\mathrm{V}$ & $\mathrm{V}$ & $\mathrm{V}$ & $\mathrm{V}$ & $\mathrm{V}$ & $\mathrm{V}$ & $\mathrm{V}$ \\
\hline 9 & - & - & $\mathrm{V}$ & $\mathrm{V}$ & $\mathrm{V}$ & $\mathrm{V}$ & $\mathrm{V}$ & $\mathrm{V}$ & - \\
\hline $\begin{array}{l}1 \\
0\end{array}$ & - & $\mathrm{V}$ & - & $\mathrm{V}$ & - & $\mathrm{V}$ & $\mathrm{V}$ & - & $\mathrm{V}$ \\
\hline $\begin{array}{l}1 \\
1\end{array}$ & - & - & $\mathrm{V}$ & - & - & $\mathrm{V}$ & - & - & - \\
\hline $\begin{array}{l}1 \\
2 \\
\end{array}$ & - & - & $\mathrm{V}$ & $\mathrm{V}$ & - & $\mathrm{V}$ & - & - & - \\
\hline $\begin{array}{l}1 \\
3 \\
\end{array}$ & - & - & - & - & - & $\mathrm{V}$ & - & - & - \\
\hline $\begin{array}{l}1 \\
4 \\
\end{array}$ & - & - & - & - & - & $\mathrm{V}$ & - & - & - \\
\hline $\begin{array}{l}1 \\
5\end{array}$ & - & - & - & - & - & $\mathrm{V}$ & - & - & - \\
\hline $\begin{array}{l}1 \\
6 \\
\end{array}$ & $\mathrm{~V}$ & - & $\mathrm{V}$ & $\mathrm{V}$ & $\mathrm{V}$ & $\mathrm{V}$ & $\mathrm{V}$ & $\mathrm{V}$ & $\mathrm{V}$ \\
\hline $\begin{array}{l}1 \\
7 \\
\end{array}$ & - & $\mathrm{V}$ & - & - & - & - & - & - & - \\
\hline $\begin{array}{l}1 \\
8 \\
\end{array}$ & - & - & - & $\mathrm{V}$ & $\mathrm{V}$ & $\mathrm{V}$ & - & $\mathrm{V}$ & $\mathrm{V}$ \\
\hline $\begin{array}{l}1 \\
9\end{array}$ & $\mathrm{~V}$ & $\mathrm{~V}$ & $\mathrm{~V}$ & $\mathrm{~V}$ & $\mathrm{~V}$ & $\mathrm{~V}$ & $\mathrm{~V}$ & $\mathrm{~V}$ & $\mathrm{~V}$ \\
\hline
\end{tabular}

Administrative type

$1=$ deed of company establishment and amendments; $2=$ letter of endorsement from the ministry (legal / cooperative); 3 = NPWP institution; 4 = ID card and NPWP management, supervisors and managers; $5=$ Savings and Loan Business License; $6=$ RAT report for the past 3 years; $7=$ Internal financial statements of the cooperative for the current year; $8=$ funding agreement and binder of collateral to members; $9=$ contract / agreement with the debtor; $10=\mathrm{CV}$ of management, supervisors and board of directors / managers; $11=$ SOP for receiving deposits / savings; $12=$ SOP of financing (types of products); $13=$ SOP for member acceptance (principal and mandatory savings); $14=$ SOP of financing problems; $15=$ SOP collectability calculation; $16=$ Organizational Structure (center and branch); 17 = Summary of financial performance; $18=$ Application for Financing; 19 = By laws (ART)

\subsection{Utilization and Capability}

Farmer respondents make use of capital borrowed from LKMA for several business groups: (i) maintaining fruit plants, especially snakeskin fruit and longan plants, (ii) growing vegetables, especially chili and leeks, (iii) raising poultry and (iv) additional businesses for grocery stores, manufacturing souvenirs for sale at the Borobudur temple and as a capital for the small food trading business. 
All farmers respondents feel that the loan interest of 1 to $1.5 \%$ per month is not burdensome. The loan period (tenor) is given for ten months. However, farmers felt that amount of loan given is small and still below the required business costs. The average loan amount is only $26.89 \%$ of the total business costs needed (Table 8 ).

From the net farm income, actually, it is still possible for farmers to increase more loans. Fruit farmers who cultivate less than 1 ha and vegetable farmers of less than 0.5 hectares can get a net income of an average of IDR 30 million. If the borrowing requirement is $30 \%$ of the net income, the farmer deserves a loan of IDR. 9 million.

Table 8. Average Use of Loans and Capability (000)

\begin{tabular}{|c|c|c|c|c|c|c|c|c|}
\hline Sector & $\begin{array}{c}\text { Borrower } \\
\text { (person) }\end{array}$ & $\begin{array}{c}\text { Loan } \\
\text { (IDR) }\end{array}$ & $\begin{array}{l}\text { Repay } \\
\text { ment } \\
\text { (IDR) }\end{array}$ & $\begin{array}{c}\text { Farm } \\
\text { Cost } \\
\text { (IDR) }\end{array}$ & $\begin{array}{c}\text { Loans / } \\
\text { business } \\
\text { costs }(\%)\end{array}$ & $\begin{array}{c}\text { Gross } \\
\text { revenue } \\
\text { (IDR) }\end{array}$ & $\begin{array}{c}\text { Net } \\
\text { revenue } \\
\text { (IDR) }\end{array}$ & $\begin{array}{c}30 \% \\
\text { Net } \\
\text { Receipt }\end{array}$ \\
\hline $\begin{array}{l}\text { Fruits: } \\
\text { Snakeskin } \\
\text { fruit }\end{array}$ & 6 & 5,000 & 5,750 & 16.348 & 30.58 & 47.126 & 30.778 & 9.233 \\
\hline Longan & 3 & 4,500 & 5,175 & 17.465 & 25.77 & 46.968 & 29.503 & 8.850 \\
\hline $\begin{array}{l}\text { Vegetables } \\
\text { Chili } \\
\text { Spring } \\
\text { Onion }\end{array}$ & $\begin{array}{l}3 \\
2\end{array}$ & $\begin{array}{l}4,000 \\
3,000\end{array}$ & $\begin{array}{l}4,600 \\
3,450\end{array}$ & $\begin{array}{l}19.730 \\
16.274\end{array}$ & $\begin{array}{l}20.27 \\
18.43\end{array}$ & $\begin{array}{l}53.703 \\
39.680\end{array}$ & $\begin{array}{l}33.973 \\
23.406\end{array}$ & $\begin{array}{r}10.191 \\
7.021\end{array}$ \\
\hline $\begin{array}{l}\text { Livestock } \\
\text { Chicken }\end{array}$ & 2 & 5,500 & 6,325 & 11.703 & 47.00 & 21.750 & 10.047 & 3.014 \\
\hline Trade: & & & & & & & & \\
\hline Shop & 4 & 3,500 & 4,025 & 25.650 & 13.65 & 56.784 & 31.134 & 9.340 \\
\hline Souvenir & 3 & 2,000 & 2.200 & 7.327 & 27.30 & 17.945 & 10.618 & 3.185 \\
\hline Food & 4 & 2,000 & 2.200 & 6.225 & 32.13 & 11.374 & 5.149 & 1.544 \\
\hline Average & & & & & 26.89 & & & \\
\hline
\end{tabular}

\section{Conclusions and Suggestion}

\subsection{Conclusion}

Microfinance institutions under the auspices of PUAP in Magelang, even though they have obtained legality from the Ministry of Cooperatives and OJK, are not the same in terms of institution naming. Some are called LKMA Cooperatives, Gapoktan LKMA Cooperatives, and some do not use the word LKMA enough with the name Koperasi Tani

LKMA Ngudi Luhur is the best LKMA, this is seen from: (i) institutional aspects that already have legality, already work in offices supported by office equipment complete with employees who are paid regularly every month and already have SOP in running a loan storage business; (ii) aspects of business implementation that are close to the borrowing requirements made by formal financial institutions and (iii) aspects of business development that experience an average capital increase of 29.86 percent per year.

The ability of LKMA venture capital loans is still relatively small. From LKMA loans, farmers can only fulfill no more than $30 \%$ of the business capital needs. Based on the net income of the farmer, the farmer is still able to pay if the loan amount is increased by 75 to $100 \%$ of the total loan given.

\subsection{Suggestion}

LKMA still faces obstacles to channeling loan assistance to farmers due to limited capital. To realize the PUAP program's objectives for overcoming capital problems in the farming, it needs a liquidity assistance to LKMA. In addition, the fulfillment of LKMA administrative requirements to become a formal financial institution should be improved. 
"Ngudi Luhur" could become as LKMA role model, in fulfilling the administrative requirements.

\section{References}

1. R. L. Meyer. IIED Working Paper. IIED, London (2015).

2. S. Mago, C. Hofisi. Environ. Econ., 7 (3): 60-66 (2016).

3. E. Adu-Gyamfi, K. A. Ampovo. J. Agric. Environ. Sci., 3 (1): 67-88 (2014).

4. N. N. BaoQuoc, J. Tsai, Int. Buss. Econ. Res. J. 13, 6. (2014).

5. M. I. Subhani and S. Awan. South Asian J. Manag. Sci. 4 (2): 23 - 28 (2010)

6. D. Sagarik, Proceeding BESSH, 76, 3: 62-76, (2016).

7. A. Sulemana, S.A. Adjei, Int. J. Ac. R. and Refl., 3, 3, 26-44 (2015)

8. I. Budiman, T. Takama, L. Pratiwi 1, E. Soeprastowo. Journal on Food, Agriculture and Society 4 (3) (2016)

9. Prastowo, A. Prasmuko, T.Chawwa. Working Paper. Bank Indonesia (2010)

10. D. Supanggih, S. Widodo. Agrieconomics Journal 2(2): 163-173. (2013).

11. L. Rahayu. Journal of Agribusiness and Rural Development Research 1(1): 52-60. (2015).

12. A. Supriatna. Agrin 16(2): 101-116. (2012).

13. Permentan. About Guidelines for Developing Rural Agribusiness in 2014 Budget Year

14. H. Sri. Agriculture Policy Analysis. 15(2): 137-149. (2017).

15. V. Darwis, I.W. Rusastra. Agriculture Policy Analysis. 9(2): 125-142 (2011).

16. C.R. Pangestika, S. Sjamsuddin, Suwondo. Journal of Public Administration 3(5): 752757. (2015).

17. P.N. Supardi, K.B. Susrusa, dan I.W. Budiasa. Agribusiness Management Journal 3(2): 121-133. (2015).

18. G.F. Zanzes, I.W. Suwendra, G.P.A.J. Susila. Journal of Bisma Ganesha University of Education Department of Management 3(1): 1-10. (2015).

19. Martiana, Hasudungan, Jufri. Journal of Agribusiness Sciences 1(1): 1-13. (2012).

20. Y. Suandi, Damayanti, Yulismi. Journal of Jambi University Humanities Research 14(2): 25-34. (2012.)

21. K. Erna, I.K. Kriya, N.N. Yulianthini. Journal of Management Department 2(1): 1-8. (2014).

22. Directorate of Agricultural Financing. Ministry of Agriculture. (2018) 